\title{
To believe or not to believe: Is that the question?
}

\author{
María S. Ciruzzi, $P h D^{a}$
}

\begin{abstract}
It is a reality that, in the field of pediatrics, parents are the legal representatives of their children, which means that any medical decision in relation to the child should be taken with the intercession of at least one of his/ her parents who -in the exercise of a subrogated autonomy and a legally granted representation- provide their informed consent. The problem arises when the parents refuse to give their informed consent or directly make decisions that will have a specific impact on their child's well-being, thus causing damage or at least a risk for damage.

The challenge here is to reconcile the interests and rights at stake, always considering that the constitutional rule of interpretation in the case of a child are his/her best interests.

Key words: parental responsibility, best interests of a child, medical care, alternative medicine.
\end{abstract}

http: / / dx.doi.org/10.5546/ aap.2018.eng.365

To cite: Ciruzzi MS. To believe or not to believe: Is that the question? Arch Argent Pediatr 2018;116(5):365-367.

Each one of us has a system of beliefs. And this system is the filter with which we build our view of the world.

a. Attorney and Criminal Law Specialist Universidad Nacional de Buenos Aires (UBA). Specialist in Bioethics (FLACSO). Ethics Committee of Hospital de Pediatría SAMIC "Prof. Dr. Juan P. Garrahan." Ethics Committee of Instituto de Investigaciones Médicas "Dr. Alfredo Lanari."

E-mail address: María S. Ciruzzi, PhD. msciruzzi@cpacf.org.ar

Funding:

None.

Conflict of interest: None.

Received: 4-17-2018 Accepted: 4-17-2018
Xavier Guix

A recent case published in the British Medical Journal triggered a series of brief considerations in relation to the interaction between science and beliefs in the field of

Often, in the context of the physician-patient relationship, some conflicts appear irreconcilable: faith and science, beliefs, doxa and episteme seem to oppose, contrast, and even devour one another without interruption. The patient is not an empty entity that attends the physician's office stripped of his / her being. The patient is a subject whose baggage includes his/her life experience, a set of facts, actions, values, and thoughts that run through and make up a person over the years. The patient is not only the subject of a disease, but his/her focus is shaped health care. according to his/her own perspective.

At first, and based on a mandate set out in Section 19 of the Constitution, autonomous decisions made by legally capable and bioethically competent people for the purpose of choosing their own life project, even if a third party perceives such decisions as irrational, ridiculous or unfounded, correspond exclusively to such adult person. It is the "right to be let alone" claimed by Anglo-American jurisprudence, where intimacy and privacy are fully and legally safeguarded provided they do not arbitrarily interfere with the rights of a third party. Considering this set of decisions, those related to self-care become particularly relevant. There is no ethical or legal duty to be healthy.

The State is forced to warrant access to a timely, high-quality health care, but is not entitled to impose it, least of all to ensure that we will not become ill.

Any medical decision is a multilateral, dynamic process that is shared and discussed between two fundamental actors: the health care team and the patient.

Such interaction between someone who possesses the scientific knowledge and someone who holds the right to life and health is not exempt from tension or reproach because it involves a somewhat "altruistic" component, which is made up of, on the one side, medical recognition that the patient has the last word regarding his/her decisions, that the patient agrees or rejects the medical proposal, and this does not mean that he/she is questioning the physician's professional skills. On the other side, the patient should admit that the health care provider is better prepared to help and guide him/her to make the most adequate, optimal, correct decision. 
In this context, the informed consent is merely the realization of the patient's autonomy. The right to self-determination, based on the understanding of the information provided by the physician in terms of diagnosis, prognosis, prescribed treatment, and alternative therapies is one of the sides of autonomy. The other side is the right to refuse treatment, stated in the Patient's Rights Act (Section 2, paragraph e, Act 26 529) and Section 59 of the National Civil and Commercial Code. That is to say, any time a consent is required to intervene on a third party's body -even with medical purposes-it means that the patient may refuse to provide his/her consent, even if it means "putting him/herself in danger." In other words, even if it means putting his/her health, and even his/her life, at risk.

In the field of pediatrics, such relation is even more complicated. The patient is no longer a fully capable person, from a legal perspective, for whom the autonomy of making decisions is recognized unrestrictedly. We are talking about a patient who is vulnerable and, many times, immature; the physician-patient relationship is no longer two-way. In this case, a third party plays a relevant role, i.e., the patient's parents and/or legal guardian and/or reliable adult caregiver.

Parental responsibility entails a set of rights and obligations regarding the child and his / her assets for the protection, development, and comprehensive education for as long as he/ she is underage and has not emancipated (Section 638 of the National Civil and Commercial Code).

Parents are the representatives of their child to protect and safeguard him/her. They are in a position known as a "guarantor" according to the legal doctrine; this means that a person is in a situation by virtue of which he/she has a specific, legal duty to act in order to prevent a typical, avoidable outcome. Some people are obliged to safeguard a certain legal asset. For example, parents are the guarantors of their child's life and freedom. This means that the State trusts a child's upbringing and care on them and should interfere when such duty is not fulfilled or is fulfilled ineffectively.

In this setting, Section 19 of the National Constitution takes a different dimension and a stricter meaning. If a child cannot express him/ herself, either because of his/her age or personal condition, and depends exclusively on the care provided by adults, such adults should assume the legal and ethical duty to care for him/her. This implies, among other things, that the child's best interests should prevail in any situation, behavior or act involving him/her, as set out in the provisions of Article 3 of the Convention on the Rights of the Child.

A child's best interests refer to the effective, specific realization of the rights that are expressly or implicitly recognized for children. ${ }^{2}$

Thus, it is considered that the child's best interest is the full adherence to his/her rights, a statement that is not at all superfluous; on the contrary, it is continuously necessary due to the generalized tendency to ignore that children's rights act as a boundary and a guidance for the actions of authorities and adults in general. ${ }^{3}$

The legal principle nature held by the best interests of a child implies that the idea, definition or conceptual development of such interests should consider the different regulatory functions acknowledged by the legal doctrine, e.g., the development of legal or regulatory standards, legal conflict resolution, guidance for public policies, family and / or private actions, etc. For such conceptual development to take place, it is best to review international regulatory bodies, which, in addition to establishing an extensive catalog of rights, recognized "children's interests" as the "higher" principle from which they derive and which they obey, in relation to their interpretation and reconciliation with one another and with other individual rights. ${ }^{2}$

"The principle's content is uncertain and subject to the understanding and extension typical of each society and historical moment, so that what is considered beneficial for a child or adolescent at present may be considered harmful in the future. It is a technical instrument that grants power to judges, who should recognize such interests specifically, depending on the case". $^{4}$

This means that a child's best interests are, above all, the interests on the child's rights here and now; it does not refer to bodily, financial or material protection; it refers, first of all, to safeguarding as many rights as possible for a particular child in a given temporary circumstance. The best interests of a child are related to his/her psychological, educational, social, legal, environmental, and resource needs. These needs are rights that have been included in international human rights instruments, the National Constitution (which embraces them), and also in other national laws. ${ }^{2}$

This means that, leaving aside personal preferences, opinions, and beliefs, "parents may not turn their children into martyrs". ${ }^{5}$ Parents 
are obliged to drop their own beliefs, values, and opinions when putting their child at risk, either by causing damage or preventing him/her from receiving adequate, scientifically appropriate, and timely medical care. Whether it is in relation to a type of diet (for example, in the case of vegetarians) or mandatory immunizations (antivaccine activists) or evidence-based medicine (advocates of alternative medicine), the best interests of a child should prevail in any situation involving a child, thus fully safeguarding and guarantying his/her rights.

There is no doubt that, in these cases, there is an almost permanent tension among parental responsibility, a child's right to education and training, the right to create a family based on one's own values and interests, the freedom of conscience (much broader than freedom of beliefs), and the right to bodily integrity and life. Once such collision occurs, it is not susceptible to a single solution, but only options. It is a true dilemma. If we choose to protect the parents' freedom of conscience in relation to a child's "non-traditional" health care, it may severely restrict the child's right to integrity and health. If, on the contrary, we opt to safeguard the child, the parents' decisions would be limited. In short, the State has a very special interest, which is also a legal mandate, to prioritize a child's rights over any other legitimate interest.

Finally, let us not miss the opportunity to underline that criminal law should not be summoned to intervene in matters of public health. Except for specific cases of parental abuse or violence, parents would hardly decide on a course of action with the purpose of harming their child. What results in the best interests of a child is usually misinterpreted, thus involuntarily exposing the child to a health risk or damage to his / her bodily integrity. Here emerges the concept of natural punishment -one that accounts for a grave damage to the offender's mental or physical health resulting immediately or directly from his / her illegal behavior-, which allows a State-given punishment to be disregarded in order to prevent it from overlapping with the burden suffered originally as a result of the offense. On the contrary, the distress that would result from the implementation of a Statesanctioned punishment would violate, in the specific case, the principle of proportionality that should mediate between the action and the punishment, and the principle of humanity, which is closely related to the former, because the offender would be criminally reprimanded twice and unequally. ${ }^{6}$

In my opinion, a mother who losses her child through an act of omission (preventing him/ her from receiving an adequate care) because she prioritized her own convictions, which may not be reprehensible as long as they are selfreferential but which violate the rights of a third party when applied to a child by someone who is also playing the role of guarantor, is already being punished enough to consider, in addition, the implementation of a criminal punishment.

Lovett, who cried repeatedly when her son's death was described, was impassive on hearing her three year sentence. "I can't begin to forgive myself", she said. "I hope others learn from my ignorance."1

\section{REFERENCES}

1. DyerO.Canadian mother whose son died from strep throat sentenced to three years in prison. BMJ 2017; 359:j5521.

2. Lora L. Discursojurídico sobre El Interés superior del niño. In Salvin P. Avances de Investigación en Derecho y Ciencias Sociales: X Jornadas de Investigadores y Becarios. Mar del Plata: Ed. Suárez; 2006. Pages 479-88.

3. Diez Ojeda A. El interés superior del niño necesidad de su regulación legal, nota al fallo de la SC de la Provincia de Buenos Aires. Buenos Aires: La Ley; 1999. Pagés 238-53.

4. Grossman C.Significado dela Convención delos Derechos del Niño en las Relaciones de Familia. Buenos Aires: La Ley; 1993.

5. U.S. Supreme Court. Prince v. Massachusetts, 321 U.S. 158. Massachusetts, January 31, 1944. [Accessed on: April 27 ${ }^{\text {th }}$, 2018]. Available at: https://supreme.justia.com/cases/ federal/us/321/158/ case.html.

6. Bacigalupo E. Teorías actuales del Derecho Penal. Buenos Aires: Ad-Hoc; 1998. 